Article

\title{
Questioning Segregation of People Living with Dementia in Australia: An International Human Rights Approach to Care Homes
}

\author{
Linda Steele ${ }^{1,2, *(\mathbb{D})}$, Kate Swaffer ${ }^{3,4}$, Lyn Phillipson ${ }^{5}$ and Richard Fleming ${ }^{3}$ \\ 1 Faculty of Law, University of Technology Sydney, P.O. Box 123, Broadway, NSW 2007, Australia \\ 2 Faculty of Law, Humanities and the Arts, University of Wollongong, Wollongong, NSW 2522, Australia \\ 3 Faculty of Science, Medicine and Health, School of Nursing, University of Wollongong, Wollongong, \\ NSW 2522, Australia \\ 4 School of Psychology, Social Work and Social Policy, University of South Australia, South Australia 5001, \\ Australia \\ 5 Faculty of Social Sciences, School of Health and Society, University of Wollongong, Wollongong, NSW 2522, \\ Australia \\ * Correspondence: linda.steele@uts.edu.au
}

Received: 1 April 2019; Accepted: 2 August 2019; Published: 15 August 2019

\begin{abstract}
This article explores how care homes-and, specifically, their common features such as dementia care units and locked doors and gates-impact on the human rights of people living with dementia. We suggest that congregation, separation and confinement of people living with dementia by the care home built environment constitute 'segregation'. In the specific context of residential aged care facilities in Australia, we draw on the United Nations Convention on the Rights of Persons with Disabilities ('CRPD') to frame this segregation as an injustice. We focus on the rights to non-discrimination (Article 5), liberty and security of the person (Article 14), equality before the law (Article 12), accessibility (Article 9), and independent living and community inclusion (Article 19). Our analysis shows that addressing segregation must involve structural and resource reforms that are transformative in bringing about new ways of living and relating to each other. Such reforms are directed towards providing meaningful alternatives and appropriate supports to make choices from a range of alternative residency and support options, and building communities that are free from ableism, ageism and other systems of oppression that contribute to confinement and segregation.
\end{abstract}

Keywords: dementia; care homes; aged care; human rights; Convention on the Rights of Persons with Disabilities; segregation; deprivation of liberty; institutionalisation; accessibility; discrimination

\section{Introduction}

An international human rights law approach to care homes provides a framework for problematising the segregation-through the aged care system-of people living with dementia and a basis for transformation to develop accommodation, support and care within the community premised on ideals of equality, inclusion and justice. To those immersed in disability studies and rights, the argument that care homes (and other disability institutions) facilitate segregation and, therefore, constitute human rights violations might seem rudimentary. Yet, there is a relative absence of human rights considerations within domestic policy debates around care homes. We take the opportunity here to set out a clear human rights case against segregation of people living with dementia through care homes and begin to plot a transformative framework for change. We are a multidisciplinary research team traversing law, public health, dementia studies, dementia care and dementia activism. 
In particular, Swaffer is a woman living with dementia and international human rights advocate for people living with dementia.

It is common for people living with dementia in Anglo-American jurisdictions to be living in large-scale residences for older people. These residences are referred to in Australia (the focus of this article) as 'residential aged care facilities', and elsewhere as 'care homes' (United Kingdom), 'long-term care facilities' or 'personal care homes' (Canada), and 'nursing homes' (USA). Many people living with dementia reside at home. However, once they require support beyond that which can be provided in their homes-through long-term formal care, informal care partners or family members-movement into a care home becomes inevitable. Generally, the decision for an individual with dementia to move into a care home is a difficult and distressing one, and is not made lightly. Yet, too often there are no other options to continue enabling care and support in the community, particularly because of long waiting periods and caps on funding for formal in-home care. Institutionalisation of older people (including those living with dementia) often occurs in response to some type of care crisis caused by an acute condition (Ariss et al. 2015; Allen et al. 1992). At times, movement into a care home can occur for people living with dementia under duress or against their will. This means many people experience limited choice and control around the decision to move into residential care.

In care homes, people living with dementia are congregated together, confined within the residence and segregated from other residents and the community at large. There are two striking features of the care home built environment that facilitate these circumstances for residents with dementia. Separate, and exclusive, 'dementia-care units' (DCUs), whether dementia wards, wings or units within mainstream care homes or 'stand-alone' facilities, segregate people living with dementia from residents without dementia. Additionally, locked doors and fences ('environmental restraint') prevent the movement of people living with dementia beyond (and usually within) the care home, meaning they have little access to social activities, full medical and health services, outdoor space and the broader community (Argyle et al. 2017). By reason of these two factors, the care home built environment is 'segregating' people living with dementia; they live in different spaces, are not afforded the same living conditions, opportunities and treatment as the rest of society, are physically prevented from interacting with the rest of society and are denied access to communal public spaces and services. This way of organising accommodation and care for people living with dementia endures, despite policies of deinstitutionalisation across various other care sectors (mental health, intellectual disability and child welfare) during the late twentieth century and the coming into force in the twenty-first century of the United Nations Convention on the Rights of Persons with Disabilities, which is premised on equality of people with disabilities-including those with dementia.

Reporting on interviews and focus groups with people living with dementia in Australia, one of the authors Swaffer (Swaffer and Low 2016) argues that people living with dementia primarily do not want to go into a care home but, if they need to, then they want choices, such as re-ablement, rehabilitation, exercise and individual lifestyle, as well as dietary choices, flexible routines, the absence of barriers and walls, and, importantly, their own keys to allow them independence to go into the community. Research has established the negative impacts of locked doors and gates. For example, Cahill notes that '[i]f internal doors are locked, people may feel displaced and, at the extreme, trapped inside' (Cahill 2018, p. 110). Dreyfus et al. (2018) argue that fences and locked gates negatively impact the emotional safety and wellbeing of people living with dementia. McSherry (2014) has observed, in the context of the mental health system, that the literature indicates adverse effects on people detained, including stigmatisation, a sense of imprisonment, social exclusion and depression. Confinement through the built environment is compounded by other forms of restraint, including chemical restraint and physical restraint (Allen and Tulich 2015). While these other forms of restraint are beyond the scope of this article, we do note that these practices may be exacerbated within more environmentally constrained facilities. Segregation not only impacts on the physical location and relative opportunities for flourishing of individual residents, but also excludes from public spaces and neighbourhoods—at a macro population level—those living with dementia, thus shaping the 
demographics of entire populations. The end result of 'out of sight, out of mind' not only impacts the safety and justice experienced by populations within these care homes but also depletes the diversity and inclusivity of our communities more broadly.

Advocacy by and for people living with dementia is increasingly drawing attention to the unjust and harmful nature of congregating, separating and confining people living with dementia in care homes, explicitly framing it as segregation (Batsch et al. 2017; Swaffer 2018, 2014b). For example, one of the authors who is an international dementia rights activist, and chair of Dementia Alliance International ('DAI'), Kate Swaffer (2018) has written: 'We know institutional care ensured worse care for orphans and people with disabilities, and moved away from that style of assisted living many years ago. DAI is campaigning globally to phase out institutional care and locked units.' She added that people living with dementia want freedom in care homes and that '[l]ocking us away, based on us having an illness, is not only a form of segregation, it is a serious breach of human rights' (Swaffer 2018; Batsch et al. 2017; Swaffer 2014b). People living with dementia have been increasingly questioning these issues globally and locally, including at venues such as the United Nations, the Conference of States Parties to the United Nation Convention on the Rights of Persons with Disabilities ('CRPD') and the World Health Organization ('WHO') (Dementia Alliance International 2018, 2017, 2016b). The concerns expressed by advocates about segregation through care homes are coupled with growing recognition of the impact of the built environment on personal wellbeing, in dementia care literature (Fleming and Bennett 2014; Fleming et al. 2016) and the emerging Dementia Friendly Communities movement (Alzheimer's Disease International 2018).

In recent years, the treatment and conditions of people living with dementia in care homes across Anglo-American jurisdictions have been the subject of increased media and legal attention and have given rise to government inquiries and NGO reports. This attention has largely been directed to discrete acts of violence, abuse and neglect against individuals within particular care homes, such as widespread use of chemical, mechanical and physical restraint, perpetration of physical and sexual assault by care staff, poor nutritional quality of food, a lack of meaningful personal relationships, a lack of opportunities for socialising and recreational activities, and medical neglect. ${ }^{1}$ In this context, the care home built environment has been indirectly positioned as the natural and unchangeable context in which action takes place, such that it is not readily seen as a source of harm and injustice. In domestic policy and aged care practice, segregating people living with dementia through care homes can be a self-evident, unquestionable and unremarkable way to organise individuals with dementia, and indeed whole populations of people living with dementia.

The WHO estimates there are 50 million people worldwide living with dementia, with ' $[\mathrm{t}$ ] he total number of people with dementia ... projected to reach 82 million in 2030 and 152 million in 2050' (World Health Organisation 2018). The WHO has identified dementia as one of the leading causes of disability and dependence in older persons and suggests that the number of people living with dementia is likely to increase due to ageing populations (Backhouse et al. 2018; World Health Organisation 2018). In this context, the use of care homes for people living with dementia is a growing practice, with institutional care of older people - even in countries such as Japan, where families traditionally and culturally were expected to provide care-becoming more prevalent (Annear et al. 2016).

As populations living with dementia increase and care homes become more widespread and embedded in geographical, social and legal landscapes, it is vital to stop and scrutinise the structural dimensions of care homes and consider transformative alternatives to how we organise accommodation, support and care for people living with dementia, and how we ensure they are included as equal and valued members of communities. Such a proposition might read as provocative given the unquestioned status of care homes in Anglo-American societies, yet we have witnessed such transformation in the

1 See Part 2 for a discussion of Australia. In the US context see, Human Rights Watch (2018). In relation to the United Kingdom, see Mowlam et al. (2007). For a Canadian perspective, see Canadian Centre for Elder Law (2011). In relation to New Zealand, see Fisher and Anderson-Bidois (2018); New Zealand Department of Internal Affairs (2019). 
context of mental health and disability deinstitutionalisation. While the shifts in these sectors have not been without their criticisms and problems (Ben-Moshe et al. 2014; Johnson and Traustadottir 2005; Perry 2015), they do offer a contrast to the context of aged care and dementia, where the focus has been on improving quality of living within care homes rather than structural transformation that moves away from large-scale institutions per se.

This article uses the case study of residential aged care facilities in Australia. We begin in Part 2 with an overview of the Australian context. In light of dementia being a disability, we draw on the rights contained in the $\mathrm{CRPD}^{2}$ to make our argument about international human rights. In Part 3, we introduce the CRPD as it relates to people living with dementia, then, in Part 4, engage with specific human rights in the CRPD. While the rights contained in the CRPD are indivisible, and so need to be considered in relation to each other, this paper focuses on specific Articles that are particularly useful. It first considers the rights to non-discrimination, liberty and equality before the law. These rights frame the injustice of segregation as a harmful and unjust intervention in the lives of individuals. The article then considers the rights to accessibility and independent living. These latter rights broaden the focus to the negative spatial and population dynamics of segregation as well as inclining towards an alternative of choice about residency and supports, resource equity and inclusion in the community. It is argued that, together, these rights provide a basis on which to frame segregation through care homes as an injustice with systemic and structural impacts at a population level. In particular, our analysis by reference to all of the rights highlights that addressing segregation cannot be solely about unlocking doors or closing large-scale institutions. Rather, it must include structural and resource reforms that are transformative in bringing about new ways of living and relating to each other-that are directed towards providing meaningful alternatives and appropriate supports to choose from a range of alternative residency and support options, and towards building communities free from ableism, ageism and other systems of oppression.

\section{People Living with Dementia in Residential Aged Care Facilities in Australia}

In 2018 it was estimated that there were 376,300 people in Australia living with dementia, although there is no available national data (Royal Commission into Aged Care Quality and Safety 2019c, p. 2). Modelling commissioned by Dementia Australia suggests that 'in 2019, 447,115 people live with dementia, with the majority of these people being women' (ibid., p. 11). It has also been noted that 'one in five people with dementia reportedly has a cultural and linguistically diverse background' and that ' $[t]$ he Aboriginal and Torres Strait Islander population is reported to have a much higher incidence and prevalence' (ibid., p. 12).

The Australian government funds two primary options for support and care for people living with dementia. One is support and care received at home. The Commonwealth Home Support Program 'is intended to provide ongoing or short-term care and support services such as help with housework, personal care, meals and food preparation, transport, shopping, allied health, social support and planned respite'. The 'Home Care Package' can include a 'range of personal care, support services, clinical services and other services' (Royal Commission into Aged Care Quality and Safety 2019a, p. 17). There is high 'unmet demand for home care' and 'at 30 September 2018, there were 69,086 people waiting for an approved level package who had not yet been offered a lower level Home Care Package ... [and] 57,646 people who, while they were waiting for a package at their approved level, had been offered an interim Home Care Package at a lower level' (ibid., p. 18). The second option is care and support outside of the home and in residential aged care accommodation. This form of care, which can be provided on a permanent or temporary respite basis, 'provides support and accommodation for people who have been assessed as needing higher levels of care than can be provided in the home'

2 UN Committee on the Rights of Persons with Disabilities (CRPD). 2008. Convention on the Rights of Persons with Disabilities (CRPD). 2515 UNTS 3. 
(ibid.). The kinds of services provided in residential aged care include 'help with day-to-day tasks (such as cleaning, cooking, laundry)', 'personal care (such as bathing, dressing, grooming, going to the toilet)', 'clinical care (such as wound care and medication administration) under the supervision of a registered nurse', and 'other care services' (ibid., p. 19). Support through the residential aged care option generally involves the provider of aged care accommodation receiving the funding, such that individuals become solely reliant upon that one service for the full scope of support and care (including supports to facilitate access to the community). Additional to these are some schemes for more flexible care, including in rural, regional and remote communities and in Aboriginal and Torres Strait Islander communities (ibid., pp. 19-20).

Generally, residential aged care in Australia applies to people over the age of 65 years. Some younger people with early onset dementia (as well as other disabilities) are also living in residential aged care facilities (Royal Commission into Aged Care Quality and Safety 2019a, p. 20; Summer Foundation 2018). However, if these younger individuals can enter the National Disability Insurance Scheme (NDIS) before turning 65 years they can have access to flexible and ongoing funding that can be used to provide in-home support or engage other services to support community access if in residential aged care. There is a longstanding advocacy to get younger disabled people with dementia out of aged care (Summer Foundation 2019). We support this advocacy, but this article is focused on the human rights issues associated with residential aged care facilities per se and with people living with dementia irrespective of age who are living in circumstances of segregation and confinement in residential aged care.

Forty-nine percent of people living with dementia live in care accommodation (such as residential aged care facilities, hospitals and other institutions that provide care, and group homes), with the remainder living in households (such as private dwellings and self-care units within retirement villages) (Australian Institute of Health and Welfare 2017, p. 2). In 2016-2017, there were 902 providers of aged care offering 200,689 residential places in 2672 facilities in Australia, at a cost to the Australian Government of AU\$11.9 billion (Aged Care Financing Authority 2018).

The traditional model of care is fundamentally underpinned by a medical model oriented towards hospital-like congregated facilities. In the early years of the current era, this led to the building of large-scale facilities with rooms leading out to long (often confusing) corridors, central eating areas, and limited access to gardens or outdoor areas. It also meant most bedrooms were share rooms, mostly twin share or four-bed 'wards' as in hospitals. While some of these facilities still exist, the reforms of 1980s, the changing demands from consumers and a greater understanding of the principles of good dementia design (Fleming and Purandare 2010) are leading to an appreciation that purposeful design of the built environment for people with dementia can improve their functioning, decrease symptoms and improve quality of life. However, the development of understanding of good design for people with dementia has not been sufficiently informed by an understanding of the rights of the person with dementia. As a result, upon visiting an Australian residential aged care facility, one is likely to encounter two core features of the built environment that are nearly universal. One feature is a dementia care unit (DCU), also referred to in some countries as 'special care units' (SCUs) or 'memory units'. DCUs, seen since the 1970s as a response to the needs of people living with dementia, are characterised by trained specialist staff, special programmes, a modified physical environment, and are usually relatively small-scale. A defining characteristic has always been their separation from other parts of the care home by means of locked doors.

The rationale for establishing DCUs was to meet the perceived need of those with dementia for security, dignified personal care, appropriate mental and physical stimulation, and protection from exploitation or abuse (Berg et al. 1991). DCUs were also developed in response to the challenge that cohabitation with people living with dementia can present to the privacy, autonomy, safety and choices of people without dementia, who wish to live in an environment free from what are considered to be the socially inappropriate and impulsive responses of some people with dementia. DCUs have been established, both as specialised sections within mainstream residential aged care facilities and as 
stand-alone facilities, in all westernised societies since the 1980s. In Australia, the exact number of such units is unclear. However, the federal government has announced its intention to build and support 31 new DCUs either within existing residential aged care facilities or as standalone facilities due to the current perceived inability of the residential aged care system to appropriately support people with severe dementia (Department of Health 2017). While DCUs might have been developed with good intentions, and have been found to provide some marginal improvements for those with advanced dementia when compared with traditional mainstream dementia care (Masso et al. 2017), these improvements might better be achieved by providing best-practice care in a well-designed, mainstream environment that supports the wellbeing of all who live and work there (Chaudhury et al. 2017; Fleming and Purandare 2010). It is clear that environments that support engagement with a variety of activities, both inside and outside facilities, provide a familiar and varied selection of private and community spaces, and the amenities and opportunities to take part in domestic activities enhance the quality of life of people living with dementia (Fleming et al. 2016).

Generally, Australian residential aged care facilities are designed with locked doors and gates which people living with dementia (and other residents) will find very difficult to unlock. Dreyfus et al. (2018), for example, have noted, that the 'fence' remains a steadfastly standard feature of residential aged care facilities. They state: 'Most nursing homes in Australia can be recognised by the 1.8-metre-high fence around them ... [P] erimeter fences are so taken for granted that even designers of outdoor spaces for nursing homes specify them as a necessity without qualification' (Dreyfus et al. 2018, p. 108). Locking is rationalised as a means to ensure the safety of people living with dementia, who present a risk to themselves and others (Smith and Sullivan 2012). This understanding of safety is focused on the physical safety of the individual; it does not consider emotional 'safety', which can be negatively impacted through confinement (Dreyfus et al. 2018). It also ignores the falls and injuries sustained in trying to escape physical confinement or other types of physical or chemical restraint used to manage people's agitation within constricted environments. This safety rationale also ignores the fact that people rarely escape from care homes, and rarely experience harm in the community even when they do (Woolford et al. 2017; Woolford and Ibrahim 2017).

While we argue that congregation, confinement and segregation through residential aged care facilities is harmful and unjust per se, it is also important to note that this might be particularly pronounced for certain populations. For example, Aboriginal and Torres Strait Islander people might experience residential aged care as another form of white settler institutionalisation compounding the lifelong and intergenerational impacts of institutionalisation through child welfare and criminal justice systems; as noted by the Northern Territory Council of Social Services,

it is important that members and descendants of the Stolen Generation do not experience further trauma through reinstitutionalisation. Placing a member or descendant of the Stolen Generation in a residential facility can risk re-traumatisation and cause further harm to the individual. Tailored services for members and descendants of the Stolen Generation that prevents re-traumatisation and supports their needs, independence and freedom are required. (Northern Territory Council of Social Services 2019, p. 5)

Moreover, residential aged care facilities can separate older Aboriginal and Torres Strait Islanders from community and Country. 'Older Indigenous patients from remote locations often find themselves bound to towns, unable to return home because of lack of services. Separation from family and country adds to generational trauma and further reduce their health and wellbeing'. (Darwin Community Legal Service 2019, p. 10; Martin 2019). 'Forgotten Australians' (i.e., people who were in the child welfare system) and individuals who experienced child abuse might also experience fear, distress and 
trauma in entering the aged care environment (Wood 2019), as might older trans people who have 'already encountered profound discrimination throughout their lives' (Keast 2015). ${ }^{3}$

The emergence of residential aged care facilities in Australia is associated with the rise of the modern welfare state and other economic transformations in the mid twentieth century. The modern history of residential aged care facilities in Australia began with the enactment of the Aged Persons Homes Act 1954 (Cth), under which the Federal Government provided capital subsidies to charitable organisations to support hostel-type accommodation. This was followed by the introduction of a Commonwealth nursing homes benefit in 1962, which opened the provision of residential aged care to the private sector. These events separate the current era of residential aged care facilities from the previous era of provision of care through poor houses and asylums (Royal Commission into Aged Care Quality and Safety 2019a, p. 2). The Royal Commission into Aged Care Quality and Safety has recently proposed that in future there will be more options for people to receive care and support in their homes as they age, but that residential aged care facilities will continue to provide accommodation, care and support for those with higher level needs (Royal Commission into Aged Care Quality and Safety 2019b, pp. 27-28), concluding that ' $[\mathrm{t}]$ he total supply of care will need to increase, with large absolute rises being required in the level of provision in each part of the aged care spectrum. At the same time, the structure of supply will need to shift, with larger increases in community care on the one hand and high-level care residential care on the other' (ibid., p. 29). It seems inevitable that despite increasing emphasis on the development of community-based services (Aged Care Financing Authority 2018) residential aged care facilities will be built and the number of people living with dementia in these facilities will increase-they will become an even more prominent feature of Australian society.

The current era of Australia's residential aged care system has been marked by a series of governmental reviews and reforms that have resulted in an extensive quality assurance infrastructure and the provision of funding based on an evaluation of the needs of the residents. However, these standards have not always resulted in the provision of adequate care (Carnell and Paterson 2017). Presently, there is a Royal Commission into Aged Care Quality and Safety (Commonwealth of Australia 2018; Royal Commission into Aged Care Quality and Safety 2019a, 2019b, 2019c, 2019d), called soon after the screening of a two-part current affairs story detailing widespread abuse and neglect in Australian residential aged care facilities (Connolly 2018). The Royal Commission came on the heels of a series of reviews in light of the abuse and neglect at the Oakden Aged Mental Health Care Service (Groves et al. 2017; Carnell and Paterson 2017; Senate Community Affairs References Committee 2018) and a Senate Community Affairs References Committee inquiry into care and management of younger and older Australians living with dementia and behavioural and psychiatric symptoms of dementia (Senate Community Affairs References Committee 2014). The circumstances for people living with dementia in residential aged care will also be considered in the context of a broader Royal Commission recently called into violence, abuse neglect and exploitation of people with disability (Commonwealth of Australia 2019), which follows two Senate Community Affairs References Committee inquiries into circumstances in disability services touching tangentially on people living with dementia in residential aged care facilities (Senate Community Affairs References Committee 2015, 2016). This current wave of inquiries and reviews is situated in a longer history of 'more than 20 such inquiries into aged care stemming back to 1997' (Phillips et al. 2018).

While these recent inquiries and reviews are highlighting the significant systemic problems experienced by individuals within residential aged care facilities, what is missing is an additional layer focused on asking larger, structural questions: why are people living with dementia locked up in residential aged care facilities? Why are people living with dementia in these facilities kept separate from residents without dementia? Why do people living with dementia not have freedom to move between these facilities and the community as they wish? Why is deinstitutionalisation of residential

3 Thank you to Rae Carr for raising this issue. 
aged care not on the reform agenda, or even part of the debate? Finally, why are these issues not politicised as human rights violations and injustices? The absence of these kinds of questions in the debates is a striking contrast to the disability support sector, where the introduction of the NDIS has put pressure on state governments to close remaining large-scale disability institutions for people with intellectual disability as part of a broader shift to greater 'choice and control' and community inclusion of people with disability (ABC News 2015; Farquhar and Tonkin 2018). Interestingly, the recent Aged Care Royal Commission background paper on restrictive practices focused only on chemical and physical restraint and did not consider environmental or architectural restraint, only going so far as to note that: 'Secluding or confining a person to a residence or a locked dementia unit may not be recognised as restraint, although such practices can significantly inhibit a resident's liberty to move within or outside the residence' (Royal Commission into Aged Care Quality and Safety 2019d, p. 5). Now is a particularly significant moment to explore human rights, segregation and related issues of institutionalisation and community inclusion in an Australian context.

\section{Human Rights and People Living with Dementia}

Human rights protections for people living with dementia in residential aged care facilities in Australia are set out in a Charter of Aged Care Rights and Aged Care Quality Standards. Lewis has recently proposed that Australian consumer law provides an additional-but hitherto unexplored-arena for enforcing rights in residential aged care (Lewis 2019). However, while these frameworks might recognise rights directed towards ensuring better quality of care and living circumstances for individuals within residential aged care facilities (which is undoubtedly important), they do not extend to rights—-such as those to liberty, equality/non-discrimination and community living - that would call into question the political legitimacy of residential aged care per se and disrupt the structural organisation of the built environment and service systems that enables segregation of people with dementia as a population.

In the Australian context, it has been noted that confinement generally occurs through informal arrangements between residential aged care facilities and family members or public guardians and, as such, without the consent of the person with dementia and generally not pursuant to a legal order enabling a third party to make substituted decisions on the person's behalf (Smith and Sullivan 2012; Allen and Tulich 2015). Absent clear legislative frameworks in Australia regulating locked doors and gates in residential aged care facilities, the legality of these can be determined retrospectively by the court through writ of habeas corpus, action in trespass, and prosecution for criminal assault offences, although in practice this rarely occurs (Allen and Tulich 2015; Chandler et al. 2018; Lewis 2019). Taken together, existing domestic laws in Australia provide a basis on which to ask 'Is an individual being treated well within an aged care facility?' and 'Is a particular individual lawfully within a facility?', but not to ask 'Are people living with dementia as a population being oppressed through the very existence of, and the built environment of, residential aged care facilities?'.

In contrast, international human rights law provide a framework for beginning to ask such questions. Segregation of racialised and poor populations has been a central concern in civil rights and human rights activism (De Leeuwet et al. 2008). Historical examples of this segregation include workhouses, racial apartheid, 'Jim Crow' laws and residential 'red-lining'. In a contemporary context, segregation manifests at multiple levels, from the macro-level walls dividing nations to micro-level gated residential communities (Callahan 2018, p. 457 fn. 5). For decades, international human rights law has provided the framework for understanding segregation as an injustice. Provisions broadly referring to the right to non-discrimination contained in various human rights instruments, such as the International Covenant on Civil and Political Rights (ICCPR) (1966) might be construed as indirectly providing the basis for contesting segregation. The greatest focus in the international human rights system on segregation has been in the context of race. The International Convention on the Elimination of Racial Discrimination (ICERD) (1969) provides that 'States Parties particularly condemn racial segregation and apartheid and undertake to prevent, prohibit and eradicate all practices of this nature 
in territories under their jurisdiction' (Art. 3) and asserts the right to equality before the law, including in relation to the 'right of access to any place or service intended for use by the general public' (Art. 5(f)). In comparison, international human rights law has historically been ineffective in recognising and responding to the segregation of people with disabilities. As Karsay and Lewis note, '[i]t is only within the last decade that the mainstream human rights community has embraced the quite obvious notion that desegregation applies in the field of disability on an equal basis to other domains such as race and ethnicity' (Karsay and Lewis 2012, p. 819).

Globally, people with dementia themselves have also been advocating for significant change. Dementia Alliance International held the first dementia focused Side Event at the 12th Session of the Conference of State Parties on the Rights of Persons with Disabilities in June 2019. This event ${ }^{4}$ was a rich discussion on dementia as a disability, and people with dementia as equal rights bearers. The event focused on the many violations people living with dementia face in the community and in care homes. These violations include, in the context of care homes, physical restraint (CRPD Arts 15, 16, 17, 18), chemical restraint (CRPD Arts 16, 17, 18), segregation (Arts 5, 9, 14), loss of freedom (Arts 12, 13, 15,18 ), isolation, loneliness, violence and abuse (Arts 15, 28).

The CRPD has been widely hailed as effecting a 'paradigm shift' in the human rights of people with disabilities (see e.g., Bartlett 2013). This perception partly relates to the recognition in the CRPD of the fundamental equality of people with disabilities to those without disabilities, and that disability is not a legitimate basis for differentiating between people. One of the implications of this core ideal of equality is that otherwise taken-for-granted and routinised ways of organising disabled populations and individuals that are premised on disability (or mental incapacity), such as disability-specific institutions, deprivations of liberty and non-consensual medical interventions, can be re-cast as discriminatory and, in some circumstances, might amount to violence-or even torture.

Cahill states that the CRPD 'allows for a new and exciting dialogue to emerge, where the framing of dementia is no longer characterized by stigma, fear and exclusion, but rather, where the individual with dementia is viewed as a legitimate part of mainstream society' (Cahill 2018, p. 66). While dementia fits within the definition of 'disability' in the CRPD, 'the dominant and most influential discourse on dementia has up until recently centred on human needs and personhood and not on human rights' and 'a rights-based approach has rarely been explicitly applied to challenge the discrimination, marginalization and exclusionary practices and policies many people living with dementia experience' (ibid., p. 73). Despite some criticism regarding the lack of inclusion of people living with dementia and their organisations in the development of the CRPD (Cahill 2018), ${ }^{5}$ there is growing momentum, particularly since 2015 , among the international community of states, UN bodies and activist organisations to address human rights issues experienced by people living with dementia (ibid.). Some scholars have considered human rights in the context of various aspects of care homes (Backhouse et al. 2018; Blackman et al. 2003; Boyle 2008; Charras et al. 2016; Green 2017; McSherry and Maker 2019; Williams 2011), and we contribute to this growing body of literature by focusing on the under considered issue of segregation.

In 2015, Rosa Kornfield-Matte, UN Independent Expert on the Enjoyment of all Human Rights by Older People, called on 'all States and other stakeholders to adopt a rights-based approach when addressing dementia', stating that '[p]ersons with dementia should be able to enjoy their rights and fundamental freedoms in any circumstances. Their dignity, beliefs, needs and privacy must be respected at all stages of the disease' (Cahill 2018, p. 3). Also in 2015, one of the authors Kate Swaffer gave a keynote speech at the WHO First Ministerial Conference on Dementia, held in Geneva, in which she also demanded human rights and access to the CRPD for people with dementia. Her demands were included in the final Call to Action (Dementia Alliance International 2015; World Health

4 https://www.dementiaallianceinternational.org/summary-of-the-dai-side-event-at-cosp12/.

5 See Cahill (2018, pp. 48, 61-62) for further discussion. For similar concerns raised in relation to people with psychosocial disabilities, see Santegoeds (2018). 
Organisation 2015). The WHO Global Action Plan for a Public Health Approach to Dementia identifies human rights (and specifically the CRPD), empowerment and accountability as three of the seven 'cross-cutting principles'. 6 These principles cannot be realised without full commitment to the CRPD and its Optional Protocol. Dementia rights advocates are increasingly using the CRPD to frame their demands for equality (Alzheimer's Disease International and Dementia Alliance International 2016; Dementia Alliance International 2016a; Swaffer 2014b). People with dementia no longer accept being advised to get their affairs in order and prepare to die. They are demanding rights to remain at work, to healthcare and, importantly, to appropriate and adequate post-diagnostic support. DAI has drawn on the CRPD to question and challenge circumstances for people living with dementia in care homes (Dementia Alliance International 2016a; Swaffer 2018, 2014b).

\section{CRPD and Residential Aged Care Facilities}

The United Nations Committee on the Rights of Persons with Disabilities ('UN Disability Committee') has stated that '[t]he segregation of persons with disabilities in institutions continues to be a pervasive and insidious problem that violates a number of the rights guaranteed under the Convention' (UN Committee on the Rights of Persons with Disabilities UN Disability Committee, para. 46). In this part, we focus on the rights provided in the CRPD to explore the injustice of segregation of people living with dementia in the Australian residential care facility built environment.

\subsection{Equality and Non-Discrimination}

The ideal of equality and non-discrimination runs throughout the CRPD and is central to our argument that residential aged facilities are unjust because they segregate people living with dementia. As such, this is a foundational place from which to re-assess the assumption that people with dementia as a group require segregation, congregation and confinement by reason of their disability, for their own protection and in their best interests.

Article 5(2) of the CRPD calls on States Parties to 'prohibit all discrimination on the basis of disability and guarantee to persons with disabilities equal and effective legal protection against discrimination on all grounds'. ${ }^{7}$ Equality and non-discrimination have been described by the UN Disability Committee as 'the cornerstones of all human rights' (UN Committee on the Rights of Persons with Disabilities UN Disability Committee, paras 4-5), 'at the heart of the [CRPD]' and running through all of the substantive rights in the CRPD (ibid., para. 7). Thus, the interpretation of other articles of the CRPD must be done in a way that recognises equality and non-discrimination.

Article 5 frames disability as a political, rather than medical and natural, dimension of identity and explicitly anticipates the possibility that the different treatment of people with disability is not automatically and self-evidently always in their best interests, therapeutic, necessary or beneficial (UN Committee on the Rights of Persons with Disabilities UN Disability Committee, para. 2). This Article provides a basis for considering the segregating effects of residential aged care facility built environments because instead of assuming people living with dementia need to be in these settings and will automatically benefit from them, we can argue that congregating and confining people in residential aged care facilities as a major and default living arrangement for people living with dementia has the purpose or effect of limiting the enjoyment of their human rights.

We argue that specific design features of residential aged care facilities, discussed in Part 2 above, are discriminatory because they limit the ability of people living with dementia to move freely within the community and, thus, limit enjoyment of their rights to liberty (Art. 14), personal integrity (Art.

6 'Policies, plans, legislation, programmes, interventions and actions should be sensitive to the needs, expectations and human rights of people with dementia, consistent with the Convention on the Rights of Persons with Disabilities and other international and regional human rights instruments' (World Health Organisation 2015).

7 See also definition of 'discrimination on the basis of disability' in Art. 2. 
17) and equality before the law (Art. 12). These features also violate their access to public space and services (Art. 9), independent living (Art. 19), participation in recreation (Art. 30), personal mobility (Art. 20), and even their ability to make an equal contribution, as a member of civil society, to political life (Art. 30).

The CRPD's definition of discrimination also includes 'structural or systemic discrimination', a more widespread discrimination that operates at the population level and is not reducible to the experiences of specific individuals (Pyaneandee 2019). Indeed, the statistics and residential aged care pathways discussed in Part 2 above highlight the structural discrimination inherent in the way the funding and service system is set up and operates. The placement of people living with dementia in residential aged care facilities is usually the result not of a state's use of physical force on resisting individuals but, rather, of more diffused and structural coercion. By this we mean that, while some people living with dementia choose to live in residential aged care facilities, often this 'choice' is actually a decision made by substituted decision-makers, such as family or public guardians. In other instances, it might be a decision made because there simply is no suitable accommodation and support available in the community, at least without joining long waiting lists. Moreover, while the NDIS might provide greater opportunities for in-home support for people living with dementia, to be eligible to receive support under the scheme in older age one must have initially entered the scheme prior to turning 65 years. Individuals living with dementia who first receive a diagnosis or only begin to require support when they are 65 years or older will not be eligible to enter the NDIS and the aged care system will be their only option for government-funded support. Therefore, while some people might choose to live in aged care, complex social and economic dynamics and a lack of alternatives shape and constrain the options available to many, while others never have the opportunity to make even a constrained choice because of the denial of legal capacity.

In recognising the discriminatory nature of institutionalisation, the UN Disability Committee has emphasised the circumstances that can force people into 'choosing' residential aged care, stating: 'Institutionalization is discriminatory as it demonstrates a failure to create support and services in the community for persons with disabilities, who are forced to relinquish their participation in community life to receive treatment' (UN Committee on the Rights of Persons with Disabilities UN Disability Committee, para. 58). For Aboriginal and Torres Strait Islander Australians with dementia, in particular, institutionalisation might also give rise to structural discrimination at the intersections of disability and Indigeneity and, moreover, impede Aboriginal and Torres Strait Islander self-determination and nation building (2017).

Until there are a range of meaningful options and processes from which to choose, it is difficult to say that people living with dementia themselves choose to live in residential aged care facilities. Viewing residential aged care facilities in terms of structural discrimination suggests the importance of a more radical transformation of support and accommodation funding and services, as well as the importance of developing coalitions with activists involved in urban planning, poverty and community development so as to enable a range of affordable and respectful accommodation and support options in the community.

Moreover, addressing residential aged care facilities as a form of discrimination needs to be understood in the context of the CRPD's 'inclusive equality' approach. This approach moves beyond formal legal equality to include fair redistributive, recognition, participative and accommodating dimensions (UN Committee on the Rights of Persons with Disabilities UN Disability Committee, para. 11). This suggests that nothing short of structural transformation of society involving the abolition of residential aged care facilities and development of alternative living arrangements, shifts in resource allocation to ensure economic equity, and cultural shifts in how dementia is understood in society more broadly, will fully realise Article 5 (Degener 2016). It is vital that concrete, effective alternatives to residential aged care facilities be developed and sustainably funded to help realise Article 5, and that support is provided to people living with dementia and their representative organisations and allies, to contribute to the development of these alternatives. Peer-led and community-based alternatives of 
accommodation and support in the context of psychosocial disabilities provide some examples of how this might be achieved in relation to people living with dementia (Ben-Moshe 2014), as do the range of Aboriginal community controlled organisations in the health and justice contexts (Behrendt et al.). A narrower approach—such as simply unlocking care home doors and/or closing large-scale institutions and leaving people living with dementia in the community unsupported-could result in other harms and rights violations of people living with dementia.

\subsection{Liberty and Security of the Person}

Confining people living with dementia within residential aged care facilities through locked doors and gates can be framed as a violation of the right to liberty and security of the person, provided for by Article 14(1)(a) of the CRPD (Pyaneandee 2019, p. 25). The UN Disability Committee has identified the right to liberty and security of the person as 'one of the most precious rights to which everyone is entitled' particularly for people with cognitive disabilities (UN Committee on the Rights of Persons with Disabilities UN Disability Committee, para. 3), and Article 14 has been identified by dementia advocacy organisations as a significant right, particularly for individuals with late- and end-stage dementia (Batsch et al. 2017). Deprivation of liberty occurs when individuals 'are confined to a restricted space or placed in an institution or setting, not free to leave, and without free and informed consent' (Special Rapporteur on the Rights of Persons with Disabilities 2019, para. 40). Article 14 requires that States Parties ensure that people with disabilities, on an equal basis with others '[e]njoy the right to liberty and security of person' and '[a]re not deprived of their liberty unlawfully or arbitrarily, and that any deprivation of liberty is in conformity with the law, and that the existence of a disability shall in no case justify a deprivation of liberty'.

Confining people living with dementia through locked doors and gates inside DCUs, within the entire care home building, or within the outer perimeter of the care home grounds, constitutes deprivation of liberty. Residents with dementia do not have the freedom to leave the premises when they choose because they do not have access to the means to unlock the doors and gates (Smith and Sullivan 2012). This deprivation of liberty is unlawful where there is no legal order in place permitting this deprivation of liberty and, as discussed in Part 2 above, it is widely understood that, in some jurisdictions, locking occurs without routinely seeking consent.

Yet, regardless of its lawfulness, deprivation of liberty through locked doors and gates can also be arbitrary if deprivation of liberty occurs on the basis of dementia (even pursuant to law), including because of 'supposed symptoms' associated with dementia (UN Committee on the Rights of Persons with Disabilities UN Disability Committee, paras 4, 6; Office of the United Nations High Commissioner for Human Rights 2009, para. 49). The Special Rapporteur on the Rights of Persons with Disabilities has recently stated that '[d]eprivation of liberty on the basis of impairment is not a "necessary evil"' but instead 'is rooted in intolerance, and in States' inaction to implement human rights' (Special Rapporteur on the Rights of Persons with Disabilities 2019, para. 86) and that 'detention of persons with disabilities based on "danger to self or others", "need of care" or "medical necessity" is unlawful and arbitrary". It is also discriminatory, because detention on this basis applies either exclusively or disproportionately to people with disabilities (notably people with dementia) who, as noted by the UN Disability Committee, are entitled to take risks on an equal basis with others (UN Committee on the Rights of Persons with Disabilities UN Disability Committee, para. 15). The Special Rapporteur further noted that detention on this basis 'can obstruct people's recovery and re-traumatize those who have previously experienced abuse' (Special Rapporteur on the Rights of Persons with Disabilities 2019, para. 61).

Framing confinement in residential aged care facilities as deprivation of liberty has quite radical implications. The Disability Committee has stated that following a breach of Article 14, individuals must be assisted in their release from the premises, and with provision of 'access to housing, means of subsistence and other forms of economic and social support' and 'compensation, as well as other forms 
of reparations' (UN Committee on the Rights of Persons with Disabilities UN Disability Committee, para. 24). ${ }^{8}$

\subsection{Equality Before the Law}

Confining people living with dementia in residential aged care facilities can constitute a violation of the right to equal recognition before the law pursuant to Article 12 of the CRPD. This involves persons with disabilities 'hav[ing] the right to recognition everywhere as persons before the law' (Art. 12(1)), 'enjoy[ing] legal capacity on an equal basis with others in all aspects of life' (Art. 12(2)) and being provided with access to 'the support they may require in exercising their legal capacity' (Art. 12(3)). The UN Disability Committee has called for 'universal legal capacity' (UN Committee on the Rights of Persons with Disabilities UN Disability Committee, para. 25), which includes abolition of practices that violate Article 12(2) and introduction of supported decision-making models and associated resources and opportunities (Art. 29). The right to equality before the law is a 'threshold right' (UN Committee on the Rights of Persons with Disabilities UN Disability Committee, para. 47) because having one's decisions legally recognised is necessary for the enjoyment of other rights that are relevant to segregation in, and through, residential aged care facilities, such as rights to liberty and independent living (UN Committee on the Rights of Persons with Disabilities UN Disability Committee).

Confinement in residential aged care facilities may violate Article 12 when people living with dementia are non-consensually locked in residential aged care facilities or DCUs. As discussed above, there are a variety of circumstances in which people living with dementia end up in residential aged care facilities, and many are there non-consensually. Article 12 will be violated in relation to those individuals living with dementia who are denied the opportunity to decide where they live because others make the decision for them, whether this is through a formal decision of a family member, guardian or public guardian pursuant to substituted decision-making regimes or informally by family members (UN Committee on the Rights of Persons with Disabilities UN Disability Committee, para. 40).

Articles 12 and 14 are arguably the most contentious articles in the CRPD and have sparked much debate amongst scholars, legal and medical practitioners and policymakers about the extent to which they require absolute autonomy of individuals with disabilities. This is compounded in Australia by the Interpretive Declaration Australia has entered into in relation to Article 12, which some argue allows Australia to meet its obligations under Article 12 even while retaining substituted decision-making regimes. Relying purely upon these rights in the context of an analysis of residential aged care may risk the issue becoming entangled in debates about individual autonomy and overlook the significant structural issues at play. These structural issues are not about whether an individual living with dementia should be able to make choices about whether they live in residential aged care, but rather about the accommodation options, as a society, we make available from which one can choose. Moreover, the focus in Article 12 on individual self-determination overlooks the centrality of collective self-determination in Indigenous communities (Hickey 2014). For all of these reasons, we argue that it is important to move beyond the individual to the population level, and draw on the CRPD to interrogate the spaces we make available for people living with dementia to live and receive support, and about how we organise populations as a whole. Articles 12 and 14 should be implemented as part of a plan/programme to enable people with dementia to live full, safe, unstigmatised lives in the community.

Structural considerations of the ethical, political and social appropriateness of residential aged care facilities per se are not a focus of debate in Australia. Instead, current debate has concentrated on

8 Note also Article 16 of the CRPD which extends to independent monitoring, rehabilitation of victims and prosecution of exploitation, violence and abuse experienced by people with disabilities. 
improving quality of living within these facilities. We now turn our attention to articles of the CRPD that provide a basis on which to re-orient the debate towards more profound and transformative deliberation on the future of residential aged care facilities as we currently know them.

\subsection{Independent Living and Community Inclusion}

Article 19 of the CRPD provides an impetus for transformation in how we provide accommodation, support and care to people living with dementia as embedded in architectural, geographical and service system contexts. Article 19, which provides the right to live independently and be included in the community, has been described as 'one of the widest ranging and most intersectional articles of the Convention and has to be considered as integral to the full implementation of the Convention' (UN Committee on the Rights of Persons with Disabilities UN Disability Committee, para. 6). Lawson identifies Article 19 as 'the first time in international human rights law' such a right has been recognised (Lawson 2008). The UN Disability Committee describes 'independent living' as meaning that 'individuals with disabilities are provided with all necessary means to enable them to exercise choice and control over their lives and make all decisions concerning their lives' ((UN Committee on the Rights of Persons with Disabilities UN Disability Committee, para. 16(a))). Being 'included in the community' has been explained as having access to support in order to 'be fully included and participate in all spheres of social life' (ibid., para. 16(b)). The UN Disability Committee has explained that 'stigma, segregation and discrimination ... can lead to violence, exploitation and abuse in addition to negative stereotypes that feed into a cycle of marginalization of persons with disabilities' (ibid., para. 5). Certainly, this is evident from reported incidents in Australia, as was discussed in Part 2 above.

States Parties are required to 'take effective and appropriate measures to facilitate full enjoyment by persons with disabilities of this right and their full inclusion and participation in the community'. These measures focus at an individual level on repealing laws that restrict choice, freeing people from institutions and providing support to people with disabilities to make choices as to where they live, so as 'to support living and inclusion in the community, and to prevent isolation or segregation from the community' (UN Committee on the Rights of Persons with Disabilities UN Disability Committee, paras 24, 47-49). Yet, Article 19 can also be seen to operate at the level of spatial arrangements and the ordering of disabled populations because, at a structural level, it requires States Parties to have deinstitutionalisation policies and reallocate resources so as to have available a range of supports and accommodation for community living and participation (ibid., para. 57; see also paras 16(c), 41, 58, 97; UN Disability Committee 2018, para. 57; Special Rapporteur on the Rights of Persons with Disabilities 2019, paras 67, 76, 87(c); UN Commissioner for Human Rights 2012, p. 9).

In a similar vein, the WHO Quality Rights Advanced Modules support deinstitutionalisation (World Health Organisation 2017b), 'strategies to end the use of seclusion, restraint and other coercive practices' (World Health Organisation 2017c) and 'creating mental health and related services free from coercion, violence and abuse' (World Health Organisation 2017a), including coercion by families, family 'advocates' or legal guardians, or, more forcibly, by hospitals to reduce 'bed blockers' by forcing people into residential aged care facilities.

It is vital not to lose sight of the 'community inclusion' aspect of Article 19. The stigma and discrimination surrounding dementia could mean that-as Milner and Mirfin-Veitch flag in the context of people with intellectual disabilities-people living with dementia becoming 'strangers' to their communities (Milner and Mirfin-Veitch 2012). They highlight a distinction between 'being in the community' versus 'being of the community' ${ }^{9}$ and emphasise that social connection to community 'through the deepening of relationship and the accumulation of shared history' is just as important as having 'places' and 'activities' within the community (ibid.). Social isolation is experienced even by community-dwelling people living with dementia. For example, in a joint statement, DAI

9 Note also the idea of 'illusion of inclusion' in community care (Gooding et al. 2017, p. 19). 
and Alzheimer's Disease International have identified 'stigma and fear of dementia in the general population' and 'under-estimation' of the capacity of people living with dementia' as the 'greatest single obstacle to the continued participation of persons with dementia in society' (Alzheimer's Disease International and Dementia Alliance International 2016, p. 2) ${ }^{10}$ These concerns underscore the importance of Article 8 of the CRPD concerning awareness-raising 'to foster respect for the rights and dignity of persons with disabilities' and to 'combat stereotypes, prejudices and harmful practices relating to persons with disabilities' (UN Committee on the Rights of Persons with Disabilities UN Disability Committee, para. 39). ${ }^{11}$ As Argyle, Dening and Bartlett state, 'social prejudice and stigma towards people with dementia should be addressed, for this not only legitimises their social exclusion, but also influences the process of resource allocation which helps to reinforce this' (Argyle et al. 2017, p. 1006). Indeed, the UN Disability Committee has noted that implementing the rights in Article 19 should extend to tackling stigma and discrimination (UN Committee on the Rights of Persons with Disabilities UN Disability Committee, para. 97) because:

Article 19 is ultimately about transforming communities. Stereotypes, ableism and misconceptions that prevent persons with disabilities from living independently must be eradicated and a positive image of them and their contributions to society must be promoted. (ibid., para. 77)

While Article 19 is a powerful right in the context of segregation of people living with dementia, the force of this right is perhaps undercut because the aspect of the Article focused on access to resources and support is of a progressive rather than immediate nature (UN Committee on the Rights of Persons with Disabilities UN Disability Committee, para. 39). The dichotomy between immediate and progressive realisation is an ongoing issue in international human rights law, but it is particularly problematic in relation to people living with dementia, whose entry in the first place into residential aged care facilities is related to resource limitations and the impact of capped funding for community care (as discussed in Part 2).

Regardless, we see Article 19 as important in highlighting the structural, spatial and population-level human rights dynamics that more closely reflect the concerns of dementia rights advocates discussed in the Introduction, not least because it prescribes some key features of the conditions for a community and built environment beyond segregation.

\subsection{Accessibility}

Article 9, like Article 19, is useful in a dual sense, providing a basis both to challenge the segregating and confining aspects of residential aged care facilities and for more inclusive and respectful communities for people living with dementia. Article 9 provides for the right to accessibility, which is directed towards 'enabl[ing] persons with disabilities to live independently and participate fully in all aspects of life' (Art. 9(1)). This obliges States Parties to 'take appropriate measures to ensure persons with disabilities have access, on an equal basis with others, to the physical environment, transportation, information and communications, including information and communications technologies, and other facilities and services open or provided to the public' (ibid.). This obligation involves 'identification and elimination of obstacles and barriers to accessibility' including '[b]uildings, roads, transportation and other indoor and outdoor facilities, including schools, housing, medical facilities and workplaces' (ibid.). Lawson has described Article 9 as 'an innovative provision which articulates, for the first time in a UN human rights treaty, a right to accessibility' (Lawson 2014, p. 380).

The UN Disability Committee has stated that 'accessibility is indeed a vital precondition for persons with disabilities to participate fully and equally in society and enjoy effectively all their human

10 See also Swaffer (2014a).

11 CRPD. 2515 UNTS 3. Art.8. See Lawson (2008, pp. 77-78) on the importance of Article 8 in addressing discrimination. 
rights and fundamental freedoms' (UN Committee on the Rights of Persons with Disabilities UN Disability Committee, para. 12) and is a 'precondition and a means to achieve de facto equality for all persons with disabilities' (UN Committee on the Rights of Persons with Disabilities UN Disability Committee, para. 40). Conversely, 'denial of access to the physical environment, transportation, information and communication technologies, and facilities and services open to the public should be viewed in the context of discrimination' (UN Committee on the Rights of Persons with Disabilities UN Disability Committee, para. 23).

Article 9 is useful in terms of structural transformation because, ex ante, it 'is a proactive, systemic duty' ((UN Committee on the Rights of Persons with Disabilities UN Disability Committee, para. 24(a))). This means that the duty does not attach to a particular individual's access needs but, rather, is related to the kinds of access needs of a particular group. Thus, Article 9 places an obligation on States Parties to attend to accessibility in anticipation of use by a particular group, rather than only being enlivened once a request is made by an individual (which instead is related to reasonable accommodation under Article 5 of the CRPD) (UN Committee on the Rights of Persons with Disabilities UN Disability Committee, para. 8.5; UN Disability Committee, para. 25). Moreover, this obligation is 'unconditional, i.e., the entity obliged to provide accessibility may not excuse the omission to do so, by referring to the burden of providing access for persons with disabilities' (UN Committee on the Rights of Persons with Disabilities UN Disability Committee, para. 25). Yet, although the obligation is unconditional and ex ante, it is to be realised progressively (UN Committee on the Rights of Persons with Disabilities UN Disability Committee, para. 41); in the meantime, individuals can seek access via reasonable accommodation (ibid., para. 42). As such, Article 9 is useful in shifting to the population dynamics of residential aged care facilities, albeit not with immediate effect.

It is arguable that at least the locked doors and gates dimension of segregation could be interpreted as constituting a violation of the right to accessibility. The UN Disability Committee has interpreted the barriers towards which Article 9 is directed as 'technical and environmental' barriers (UN Committee on the Rights of Persons with Disabilities UN Disability Committee, para. 3), and locks constitute an environmental barrier to accessing public space. In this respect, Article 9 extends to barriers related to people being able to leave their home to physically travel between home and public space/services. On this basis, it is argued that Article 9 requires the removal of those residential aged care facilities features that prevent entry and exit to travel between one's care home and public spaces and services. Moreover, the locking in DCUs of people living with dementia within residential aged care facilities with the consequence that they cannot access shared, social and recreational spaces within the facility and the full range of excursions and activities beyond the facility which are available to other residents, we suggest is a further dynamic of discrimination related to accessibility. For example, the UN Disability Committee has explained that design should 'contribute to the creation of an unrestricted chain of movement for an individual from one space to another, including movement inside particular spaces, with no barriers.' (ibid., para. 15; emphasis added). It should be noted, however, that Lawson has expressed uncertainty about the full scope of Article 19. Lawson suggests that 'accessible' in Article 9 'appears to bear a meaning narrower than that of the phrase "access to"'. She elaborates that:

while a right to have 'access to' places, services and facilities open to the public would require them to be 'accessible', it would also require that access was not denied for reasons other than lack of accessibility-for example, by virtue of directly discriminatory rules expressly prohibiting entry to people on the basis of personal characteristics. (Lawson 2018, pp. 274-75)

Noting that the UN Disability Committee has not resolved this issue, she concludes that whether Article 9 has a role to play in requiring "“access to" facilities, services, and environments beyond accessibility' is 'an interesting question which is worth pondering' (ibid., p. 5).

Notwithstanding Lawson's reflections, we argue that even on a narrow reading of the provision, Article 9 should extend to removal of locks that prevent access to public spaces. This argument draws support from an Individual Communication in which the UN Disability Committee decided that 
barriers to leaving one's private home could constitute a violation of Article 9. The UN Disability Committee's views in Bacher $v$ Austria (UN Committee on the Rights of Persons with Disabilities UN Disability Committee) concerned the construction of a roof built to prevent weather damage to a ramp and ensure safe use of ramp. The ramp was used by the complainant to come to, and from, his house, including attending various medical and hospital appointments. A neighbour argued it violated his right of way and commenced legal action. Ultimately, a court ordered the roof be demolished and this made the complainant's access to and from the property very difficult. Indeed, his mother broke her arm assisting him on the deteriorated path. In finding a violation of Article 9, the UN Disability Committee noted that 'the destruction of the roof on the path leading to the house of the Bacher family does not only limit Mr. Bacher's access to his home, but also limits his access to social activities and to the public services that he needs for his daily life, such as education, health institutions and public services at large'.

Even where done for their own safety, locking people living with dementia in residential aged care facilities still constitutes a breach of Article 9. In Nyutsi and Takacs v Hungary (UN Committee on the Rights of Persons with Disabilities UN Disability Committee), the UN Disability Committee rejected Hungary's argument that ATMs could not be made accessible to blind people as this would pose a safety risk to them. Of the UN Disability Committee's views, Lawson has observed:

Refusing to remove an access barrier on the ground that a disabled person may thereby be at more risk of becoming a victim of crime runs totally contrary to the CRPD's principles of equality, inclusion and participation and should have no place in assessments of the effectiveness or desirability of possible reasonable accommodation measures or of plans to enhance accessibility. (Lawson 2014, p. 392)

In light of the particular circumstances giving rise to inaccessibility in the context of residential aged care facilities, it is vital that Article 9 be realised in conjunction with Article 14 so that the pervasiveness of institutionalisation, coercive interventions and deprivation of liberty do not render the accessibility of public spaces redundant. Interestingly, the UN Disability Committee has not explored issues surrounding the relationship between Articles 14 and $9^{12}$ and how deprivation of liberty through restrictive practices causes inaccessibility to public space (UN Committee on the Rights of Persons with Disabilities UN Disability Committee, para. 37). Moreover, it is also important to be mindful of Article 19 and related articles pertaining to provision of support, given that access to support staff and transport will be required at times to enable people to move beyond the locked doors of their facilities. It is also vital to address cultural and stigma barriers to access. Interestingly, the Dementia Friendly Communities movement has been taking a broader approach to access focused on cultural ideas about dementia, thus providing some foundation for developing within international human rights jurisprudence a more nuanced and realistic notion of accessibility as it relates to dementia (Alzheimer's Disease International and Dementia Alliance International 2016; Batsch et al. 2017). ${ }^{13}$

To conclude, Article 9 provides an important shift from viewing segregation in residential aged care facilities only on an individual level, to seeing how segregation is complicit in the inaccessibility of public space, by looking at the impact of the built environment and infrastructure on accessibility at the group level (in being ex ante). While Article 19 provides the impetus to fundamentally reorganise how dementia accommodation and care is provided, Article 9 is fundamental to creating communities that can welcome and include people living with dementia.

12 Interestingly, however, the UN Disability Committee has stated that Articles 14 and 19 are interrelated and that '[e]njoyment of the right to liberty and security of the person is central to the implementation of Article 19 on the right to live independently and be included in the community' (UN Committee on the Rights of Persons with Disabilities UN Disability Committee, para. 9).

13 Argyle et al. (Argyle et al. 2017, p. 1005) state that Article 9 is relevant to access for outdoor space but do not elaborate. 


\section{Where to from Here?}

By drawing on the CRPD to re-evaluate the situation of residential aged care facilities in Australia, we have shown that it is a useful tool for arguing that segregation, in the form of care homes, of people living with dementia is a human rights violation. This article provides a basis on which to engage policymakers and dementia care stakeholders in reconsidering 'self-evident' and taken-for-granted structural conditions of aged care systems and material aspects of the residential aged care facility built environment that shape the lives of people with dementia. As Quinn and Stein state, the value of the CRPD is 'to transform the entrenched and exclusionary default setting' (Quinn and Stein 2009, p. 27). Segregation as a concept is widely known by reference to its racial and class connotations, and casting care homes in this context might enable those invested (emotionally, politically and, indeed, financially) in the current status quo to experience defamiliarisation in relation to taken-for-granted practices and, hence, disrupt deeply held views and logics about dementia. As Kelly and Innes state: 'Of fundamental importance is for [human rights] principles to move beyond the rhetoric of policy and become embedded within an everyday human rights-based culture of care' (Kelly and Innes 2013, p. 62). ${ }^{14}$ Beyond engaging care staff with human rights, the article also raises important human rights issues for architects, planners and interior designers, particularly at the intersections of disability, urban planning, building design and segregation.

This analysis has raised five important issues that offer scholars and activists guidance for further exploration of segregation and dementia. The first relates to the UN Disability Committee's jurisprudence. We note that none of the UN's individual communications specifically relate to people living with dementia, and the Concluding Observations related to institutionalisation and deprivation of liberty focus heavily on psychiatric institutions. We see a need for more explicit engagement by the UN Disability Committee with people living with dementia in the development of its jurisprudence. Disability activists involved in shadow reports, and lawyers and advocates involved in making individual communications to the UN Disability Committee, might also consider strategic engagement with dementia.

Secondly, it is vital that the development of a convention for older people ${ }^{15}$ consider the circumstances of older people living with dementia in care homes, notably issues of coercive control, isolation, detention and segregation. Any such convention should also avoid 'bespoke' interpretations of political concepts, such as segregation and violence, that support more limited and technical interpretations in relation to people living with dementia when compared to other groups and that accommodate practices as being in their 'best interests' or for their 'protection'. Any such convention should also engage with economic dynamics, such as the impact of poverty on people's ability to exercise real choice in where they live and on the supports they receive, as well as the economic incentives for governments and corporations to sustain the current care home system and redirect resources and energy away from developing meaningful alternatives. The particular context of Indigenous and First Nations peoples with dementia should also be considered, notably situating aged care accommodation, support and care in a broader context of collective First Nations self-determination and nation-building. Moreover, while it is vital that reforms achieve their purpose, it is also important to ensure that they include processes for reparations for past injustices (Minkowitz 2007), and that there is public recognition, for example, through memorialisation and apologies.

The third is a need for greater comparative legal and theoretical analysis of segregation, as it is understood in relation to dementia, noting that the CRPD stops short of explicitly providing a general right or principle in relation to segregation ( $\mathrm{cf}$ the International Convention on the Elimination of Racial Discrimination). Moreover, being mindful that people living with dementia might be segregated

14 See also Clough and Brazier (2014, p. 133).

15 See, generally, the work of the United Nations Open-ended Working Group on Ageing for the purpose of strengthening the protection of the human rights of older persons, available at: social.un.org/ageing-working-group/. 
on multiple bases (for example, disability and age, disability and race, disability and poverty, disability and gender or sexual identity) and that women living with dementia are particularly vulnerable to violence, it is vital to bring a more nuanced analysis to segregation that can explore interlocking systems of oppression and how these play out in the care home context. This could also extend to building more political alliances across different anti-oppression groups working towards ending segregation. ${ }^{16}$

The fourth implication is the need to resolve the tension between immediate implementation (of civil and political rights-for example, ending detention and denial of legal capacity) and progressive realisation (of economic, social and cultural rights-for example, providing supports for decision-making and community living). While this is a well-worn human rights debate, this tension needs to be considered in the context of the immensely profitable and marketised context of care homes (Aubrecht and Keefe 2016), which might set it apart from other disability service contexts. Questions could be asked about the economic incentives for stakeholders to maintain the status quo of institutionalisation, and hence of segregation - both through the very existence of care homes and the use of DCUs and locks (and other forms of restrictive practices) as a means of efficiency in care provision. ${ }^{17}$ Conversely, it is important to consider how poorer and socially isolated people living with dementia might be more vulnerable to segregation (and the harms within institutions). ${ }^{18}$

The fifth suggestion is practical rather than legal in nature. It is vital that more resources and energy are channelled into developing concrete, meaningful and sustainable alternatives to segregation in care homes. So long as this does not occur, it is all too easy for policy and dementia care sectors to see the current, deeply entrenched status quo as the only viable option. Moreover, the design of future care homes, given that there will likely be at least one more generation of them, needs to take into account the likelihood that future residents will demand access to their communities, and higher levels of autonomy within the care home- that in our quest to build better communities beyond care homes, we must attend to the immediate needs of those still locked within them.

This article contributes to international human rights jurisprudence and scholarship on dementia. It will also, ideally, contribute to dementia care practice by providing the opportunity to disrupt conventional logics and transform individual and collective perspectives on the political status of people living with dementia. It highlights that what matters is not merely 'good practice in dementia care but also ... rights and social justice' (Argyle et al. 2017, p. 1005). While human rights have legal implications, they also have broader ethical or philosophical possibilities in providing a framework for 'how people (not just governments) treat other people and how human rights connect all of us to each other through shared rights and responsibilities' (Cahill 2018, p. 10). It is important to note that dementia care practitioners and academics have been oriented towards improving conditions in care homes, and that there have been some improvements. However, there is a need to question the moral, ethical and political foundations of segregating people living with dementia in care homes. This article is but one small contribution to this task which the authors hope opens up possible strategies for structural solutions that engage the dementia care sector and builds new coalitions with other marginalised groups in order to truly transform society.

Author Contributions: L.S. lead the research and writing of the original draft manuscript and the revision of subsequent drafts. K.S. contributed to the original draft manuscript. She also reviewed subsequent drafts and approved the final submission. L.P. contributed to the original draft manuscript. She also reviewed subsequent drafts and approved the final submission. R.F. contributed to the original draft manuscript. He also reviewed subsequent drafts and approved the final submission.

Funding: This research was funded by Dementia Australia Research Foundation-Victoria Project Grant for the project 'Safe and just futures for people living with dementia in residential aged care' (grant number: 711-1981)

16 For a discussion of this in relation to disability generally (albeit not specific to dementia), see Ben-Moshe (2011).

17 UN Commissioner for Human Rights (UNCHR, p. 39).

18 For example, see Lipmann (2009) on the issues encountered by those who cannot access aged care. 
and by Law Health Justice Research Centre, Faculty of Law, University of Technology Sydney.,Phillipson is supported by an NHMRC-ARC Dementia Research Development Grant (APP1107401).

Acknowledgments: Thank you to the anonymous reviewers and to Rachel Bolton, Beth Goldblatt, Jill Stavert and Michael Thomson for feedback on earlier drafts. Thank you to Nicola Colagiuri and Erol Dulagil for their research assistance, and to Matthew Sidebotham for copyediting. This article is funded by Dementia Australia Research Foundation-Victoria Project Grant for project 'Safe and Just Futures for People Living with Dementia in Residential Aged Care'.

Conflicts of Interest: The authors declare no conflict of interest.

\section{References}

ABC News. 2015. Sandhurst Centre 'Deinstitutionalisation' Continues Amid New Homes Planning Says Minister Martin Foley. November 9. Available online: www.abc.net.au/news/2015-11-09/progress-made-on-sandhurstcentre-deinstitutionalisation/6923222 (accessed on 14 July 2019).

Aged Care Financing Authority. 2018. Sixth Report on the Funding and Financing of the Aged Care Sector; July. Available online: www.agedcare.health.gov.au/sites/g/files/net1426/f/documents/08_2018/acfa_sixth_report_ 2018_text_fa3.pdf/ (accessed on 10 December 2018).

Allen, Judy, and Tamara Tulich. 2015. I Want to Go Home Now: Restraint Decisions for Dementia Patients in Western Australia. Law in Context: A Socio-Legal Journal 33: 1-23.

Allen, Isobel, Deborah Hog, and Sheila Peace. 1992. Elderly People: Choice, Participation and Satisfaction. London: Policy Studies Institute, Available online: psi.org.uk/publications/archivepdfs/Elderly/TAB8.pdf (accessed on 10 December 2018).

Alzheimer's Disease International. 2018. Dementia Friendly Communities. Available online: alz.co.uk/dementiafriendly-communities (accessed on 3 November 2018).

Alzheimer's Disease International and Dementia Alliance International. 2016. Access to CRPD and SDGs by Persons with Dementia. Available online: www.dementiaallianceinternational.org/wp-content/uploads/2016/ 10/ACCESS-TO-CRPD-AND-SDGs-BY-PERSONS-WITH-DEMENTIA.pdf (accessed on 10 December 2018).

Annear, Michael, Junko Otani, and Joanna Sun. 2016. Experiences of Japanese Aged Care: The Pursuit of Optimal Health and Cultural Engagement. Age and Ageing 45: 753-56. [CrossRef] [PubMed]

Argyle, Elaine, Tom Denning, and Peter Bartlett. 2017. Space, the Final Frontier: Outdoor Access for People Living with Dementia. Aging \& Mental Health 21: 1005-6.

Ariss, Stephen M., Pamela M. Enderby, Tony Smith, Susan A. Nancarrow, Mike J. Bradburn, Deborah Harrop, Stuart G. Parker, Ann McDonnell, Simon Dixon, Tony Ryan, and et al. 2015. Factors Predicting Admission to Institutional Care among Intermediate Care Service Users. Health Services and Delivery Research; no. 3.1. Available online: www.ncbi.nlm.nih.gov/books/NBK269522/pdf/Bookshelf_NBK269522.pdf (accessed on 10 December 2018).

Aubrecht, Katie, and Janice Keefe. 2016. 'Everybody has Different Levels of Why They are Here': Deconstructing Domestication in the Nursing Home Setting. In Disabling Domesticity. Edited by Michael Rembis. New York: Palgrave Macmillan, pp. 215-39.

Australian Institute of Health and Welfare. 2017. Australia's Welfare 2017. Available online: aihw.gov.au/getmedia/ 3637f3da-fd89-4233-b703-e00ae93e7d74/aihw-australias-welfare-2017-chapter5-2.pdf.aspx (accessed on 10 December 2018).

Backhouse, Tamara, Bridget Penhale, Richard Gray, and Anne Killet. 2018. Questionable Practices Despite Good Intentions: Coping with Risk and Impact from Dementia-Related Behaviours in Care Homes. Ageing $\mathcal{E}$ Society 38: 1933-58.

Bartlett, Peter. 2013. Implementing a Paradigm Shift: Implementing the Convention on the Rights of Persons with Disabilities in the Context of Mental Disability Law. In Torture in Healthcare Settings: Reflections on the Special Rapporteur on Torture's 2013 Thematic Report. Washington: Centre for Human Rights and Humanitarian Law, Available online: eprints.nottingham.ac.uk/2486/1/Paradigm_Shift_for_open_access_pub.pdf (accessed on 10 December 2018).

Batsch, Nicole, Peter Mittler, and Diane Kingston. 2017. Brief for Alzheimer Associations: Access to the United Nations Convention on the Rights of Persons with Disabilities by People Living with Dementia. Ankeny: Dementia Alliance International and Alzheimer's Disease International, Available online: www.alz.co.uk/sites/default/files/ pdfs/crpd-brief-alzheimer-associations.pdf (accessed on 6 August 2018). 
Behrendt, Larissa, Amanda Porter, and Alison Vivian. Forthcoming. Aboriginal Self-Determination in the Victorian Justice Context: Towards an Aboriginal Community Controlled Justice System. Sydney: Jumbunna Institute for Indigenous Education and Research, University of Technology Sydney (on file with first author).

Ben-Moshe, Liat. 2011. Disabling Incarceration: Connecting Disability to Divergent Confinements in the USA. Critical Sociology 39: 385-403. [CrossRef]

Ben-Moshe, Liat. 2014. Alternatives to (Disability) Incarceration. In Disability Incarcerated: Imprisonment and Disability in the United States and Canada. Edited by Liat Ben-Moshe, Chris Chapman and Allison C. Carey. New York: Palgrave Macmillan, pp. 255-72.

Ben-Moshe, Liat, Chris Chapman, and Allison C. Carey, eds. 2014. Disability Incarcerated: Imprisonment and Disability in the United States and Canada. New York: Palgrave.

Berg, Leonard, Kathleen C. Buckwalter, Paul K. Chafetz, Lisa P. Gwyther, Douglas Holmes, Kathleen M. Koepke, M. Powell Lawton, David A. Lindeman, Jay Magaziner, and Katie Maslow. 1991. Special Care Units for Persons with Dementia. Journal of the American Geriatrics Society 39: 1229-36. [CrossRef] [PubMed]

Blackman, Tim, Lynne Mitchell, Elizabeth Burton, Mike Jenks, Maria Parsons, Shibu Raman, and Katie Williams. 2003. The Accessibility of Public Spaces for People with Dementia: A New Priority for the 'Open City'. Disability $\mathcal{E}$ Society 18: 357-71.

Boyle, Geraldine. 2008. Autonomy in Long-Term Care: A Need, a Right or a Luxury? Disability E Society 23: 299-310.

Cahill, Suzanne. 2018. Dementia and Human Rights. Bristol: British Policy Press.

Callahan, William A. 2018. The Politics of Walls: Barriers, Flows, and the Sublime. Review of International Studies 44: 456-81. [CrossRef]

Canadian Centre for Elder Law. 2011. Moving from Scrutiny to Strategy: An Analysis of Key Canadian Elder Abuse and Neglect Cases: The Counterpoint Project-Discussion Paper. Available online: www.bcli.org/sites/default/files/ Counterpoint_Project_discussion_paper.pdf (accessed on 7 December 2018).

Carnell, Kate, and Ron Paterson. 2017. Review of National Aged Care Quality Regulatory Processes. Available online: agedcare.health.gov.au/sites/g/files/net1426/f/documents/10_2017/review_report_final_23_october_ 2017.pdf (accessed on 10 December 2018).

Chandler, Kim, Ben White, and Lindy Willmott. 2018. Safeguarding Rights to Liberty and Security Where People with Disability are Subject to Detention and Restraint: A Rights-based Approach (Part One). Psychiatry, Psychology and Law 25: 465-70. [CrossRef]

Charras, Kevin, Colette Eynard, and Géraldine Viatour. 2016. Use of Space and Human Rights: Planning Dementia Friendly Settings. Journal of Gerontological Social Work 59: 181-204. [CrossRef] [PubMed]

Chaudhury, Habib, Heather A. Cooke, Heather Cowie, and Leila Razaghi. 2017. The Influence of the Physical Environment on Residents with Dementia in Long-Term Care Settings: A Review of the Empirical Literature. The Gerontologist 58: 325-37. [CrossRef] [PubMed]

Clough, Beverley, and Margaret Brazier. 2014. Never Too Old for Health and Human Rights. Medical Law International 14: 133-56. [CrossRef]

Commonwealth of Australia. 2018. Royal Commission into Aged Care Quality and Safety: Terms of Reference. Available online: https://agedcare.royalcommission.gov.au/Documents/acrc-signed-letters-patent-6-Dec-2018.pdf (accessed on 13 July 2019).

Commonwealth of Australia. 2019. Royal Commission into Violence, Abuse, Neglect and Exploitation of People with Disability: Terms of Reference. Available online: https:/disability.royalcommission.gov.au/Documents/ disability-royal-commission-letters-patent-scanned-copy.pdf (accessed on 13 July 2019).

Connolly, Anne. 2018. Who Cares? Four Corners. September 17. Available online: www.abc.net.au/4corners/whocares/10258290 (accessed on 14 July 2019).

Darwin Community Legal Service. 2019. Submission to the Royal Commission on Aged Care Quality and Safety. Available online: www.dcls.org.au/wp-content/uploads/2019/05/Submission-to-the-Royal-Commission-onAged-Care-Quality-and-Safety-final_.pdf (accessed on 14 July 2019).

De Leeuwet, Michael B., Megan K. Whyte, Dale Ho, Catherine Meza, and Alexis Karteron. 2008. The Current State of Residential Segregation and Housing Discrimination-The United States' Obligations under the International Convention on the Elimination of All Forms of Racial Discrimination. Michigan Journal of Race and Law 13: 337-89.

Degener, Theresia. 2016. Disability in a Human Rights Context. Laws 5: 8-17. [CrossRef] 
Dementia Alliance International. 2015. DAI Update on the First WHO Ministerial Conference on Dementia. March 20. Available online: www.dementiaallianceinternational.org/dai-update-on-the-first-who-ministerialconference-on-dementia/ (accessed on 10 December 2018).

Dementia Alliance International. 2016a. The Human Rights of People Living with Dementia: From Rhetoric to Reality. Available online: www.dementiaallianceinternational.org/wp-content/uploads/2016/05/Human-Rights-forPeople-Living-with-Dementia-Rhetoric-to-Reality.pdf (accessed on 10 December 2018).

Dementia Alliance International. 2016b. The UN Human Rights Council-Social Forum (Update 3 of 4). December 9. Available online: www.dementiaallianceinternational.org/un-human-rights-council-social-forum-update-34/ (accessed on 10 December 2018).

Dementia Alliance International. 2017. DAI Attends MHGAP Forum 2017. October 16. Available online: https://dementiaallianceinternational.org/dai-attends-mhgap-forum-2017/ (accessed on 10 December 2018).

Dementia Alliance International. 2018. Civil Society Forum-Day 2 Update. July 18. Available online: https: //dementiaallianceinternational.org/civil-society-forum-day-2-update/ (accessed on 10 December 2018).

Department of Health. 2017. Specialist Dementia Care Units: Consultation Paper November 2017; Australian Government. Available online: https://consultations.health.gov.au/ageing-and-aged-care/specialistdementia-care-units/ (accessed on 10 December 2018).

Dreyfus, Shoshana, Lyn Phillipson, and Richard Fleming. 2018. Staff and Family Attitudes to Fences as a Means of Detaining People with Dementia in Residential Aged Care Settings: The Tension between Physical and Emotional Safety. Australian Journal of Social Issues 53: 107-8. [CrossRef]

Farquhar, Liz, and Emma Tonkin. 2018. NSW Government Urged to Explain Delays in Building New Disability Homes. ABC Newcastle. May 28. Available online: www.abc.net.au/news/2018-05-28/families-left-in-limboafter-disability-homes-delayed/9806878 (accessed on 14 July 2019).

Fisher, Mark, and Janet Anderson-Bidois. 2018. This Is Not My Home: A Collection of Perspectives on the Provision of Aged Residential Care without Consent. Wellington: Human Rights Commission, Available online: hrc.co.nz/files/1315/3471/5450/HRC_This_is_not_my_Home.pdf (accessed on 10 December 2018).

Fleming, Richard, and Kirsty A. Bennett. 2014. Environments That Enhance Dementia Care: Issues and Challenges. In Older People: Issues and Innovations in Care. Edited by Rhonda Nay, Sally Garratt and Deirdre Fetherstonhaugh. Chatswood: Elsevier Australia, p. 411.

Fleming, Richard, and Nitin Purandare. 2010. Long-term Care for People with Dementia: Environmental Design Guidelines. International Psychogeriatrics 22: 1084-96. [CrossRef]

Fleming, Richard, Belinda Goodenough, Lee-Fay Low, Lynn Chenoweth, and Henry Brodaty. 2016. The Relationship between the Quality of the Built Environment and the Quality of Life of People with Dementia in Residential Care. Dementia 15: 663-80. [CrossRef]

Gooding, Piers, Julie Anderson, and Keith McVilly. 2017. Disability and Social Inclusion 'Down Under': A Systematic Literature Review. Journal of Social Inclusion 8: 5-26.

Green, Caroline Emmer De Albuquerque Green. 2017. Exploring Care Home Providers' Public Commitments to Human Rights in Light of the United Nations Guiding Principles on Business and Human Rights. The Journal of Adult Protection 19: 357-67. [CrossRef]

Groves, Aaron, Dell Thomson, Duncan McKellar, and Nicholas Proctor. 2017. The Oakden Report: The Report of the Oakden Review; Department for Health and Ageing, South Australia. Available online: www.sahealth. sa.gov.au/wps/wcm/connect/4ae57e8040d7d0d58d52af3ee9bece4b/Oakden+Report+Final+Email+Version. pdf?MOD=AJPERES\&CACHEID=ROOTWORKSPACE-4ae57e8040d7d0d58d52af3ee9bece4b-mbuk16f (accessed on 10 October 2018).

Hickey, Huhana. 2014. Indigenous People with Disabilities: The Missing Link. In Human Rights and Disability Advocacy. Edited by Maya Sabatello and Marianne Schulze. Philadelphia: University of Pennsylvania Press, pp. 157-69.

Human Rights Watch. 2018. 'They Want Docile': How Nursing Homes in the United States Overmedicate People with Dementia. Available online: www.hrw.org/sites/default/files/report_pdf/us_nursinghomes0218_web.pdf (accessed on 10 October 2018).

Johnson, Kelley, and Rannveig Traustadottir, eds. 2005. Deinstitutionalization and People with Intellectual Disabilities: In and Out of Institutions. Philadelphia: Jessica Kingsley Publishers.

Karsay, Dorottya, and Oliver Lewis. 2012. Disability, Torture and Ill-treatment: Taking Stock and Ending Abuses. The International Journal of Human Rights 16: 816-30. [CrossRef] 
Keast, Jackie. 2015. Older Trans People Have an 'Absolute Fear' about Entering Aged Care. Australian Ageing Agenda. October 30. Available online: https://www.australianageingagenda.com.au/2015/10/30/older-transpeople-have-an-absolute-fear-about-entering-aged-care/ (accessed on 14 July 2019).

Kelly, Fiona, and Anthea Innes. 2013. Human Rights, Citizenship and Dementia Care Nursing. International Journal of Older People Nursing 8: 62-66. [CrossRef] [PubMed]

Lawson, Anna. 2008. People with Psychosocial Impairments or Conditions, Reasonable Accommodation and the Convention on the Rights of Persons with Disabilities. Law in Context: A Socio-Legal Journal 26: 62-76.

Lawson, Anna. 2014. Accessibility Obligations in the UN Convention on the Rights of Persons with Disabilities: Nyusti \& Takacs v Hungary. South African Journal on Human Rights 30: 380-92.

Lawson, Anna. 2018. Article 9: Accessibility. In The UN Convention on the Rights of Persons with Disabilities: A Commentary. Edited by Ilias Bantekas, Michael Ashley Stein and Dimitris Anastasiou. Oxford: Oxford University Press, pp. 258-86.

Lewis, Rodney. 2019. Submission to the Royal Commission for Aged Care: Unlawful Restraint in Aged Care: A Legal Perspective on Restrictive Practices and its Consequences. Elderlaw Legal Services, April 26, unpublished work.

Lipmann, Bryan. 2009. Elderly Homeless Men and Women: Aged Care's Forgotten People. Australian Social Work 62: 272-86. [CrossRef]

Martin, Lisa. 2019. 'My Heart is Crying': Indigenous Elders Face Death Far from Home Amid Aged Care Shortages'. The Guardian Online. July 12. Available online: ww.theguardian.com/australia-news/2019/jul/12/ my-heart-is-crying-indigenous-elders-face-death-far-from-home-amid-aged-care-shortages (accessed on 14 July 2019).

Masso, Malcolm, Cathy Duncan, Pam Grootemaat, Lyn Phillipson, Peter Samsa, Dave Fildes, and Rob Gordon. 2017. Evidence Check: Specialist Dementia Care Units. Sax Institute: Available online: www.saxinstitute.org.au/ wp-content/uploads/Specialist-dementia-care-units_FINAL.pdf (accessed on 10 December 2018).

McSherry, Bernadette. 2014. Locked Mental Health Wards: The Answer to Absconding? Journal of Law and Medicine 22: 17-21.

McSherry, Bernadette, and Yvette Maker. 2019. Regulating Restraint Use in Mental Health and Aged Care Settings: Lessons from the Oakden Scandal. Alternative Law Journal 44: 29-36.

Milner, Paul, and Brigit Mirfin-Veitch. 2012. 'I Am Here': The Article 19 Project. Available online: www.donaldbeasley. org.nz/assets/Uploads/publications/article-19-research-full-report.pdf (accessed on 11 October 2018).

Minkowitz, Tina. 2007. The United Nations Conventions on the Rights of Persons with Disabilities and the Right to Be Free From Nonconsensual Psychiatric Interventions. Syracuse Journal of International Law and Commerce 34: 405-28.

Mowlam, Alice, Rosalind Tennant, Josie Dixon, and Claudine McCreadie. 2007. UK Study of Abuse and Neglect of Older People: Qualitative Findings. London: National Centre for Social Research, King's College, London, Available online: http://assets.comicrelief.com/cr09/docs/older_people_abuse_report.pdf (accessed on 7 December 2018).

New Zealand Department of Internal Affairs. 2019. Abuse in Care Royal Commission of Inquiry. Available online: https://abuseinstatecare.royalcommission.govt.nz/ (accessed on 13 July 2019).

Northern Territory Council of Social Services. 2019. NTCOSS Submission to the Royal Commission into Aged Care Quality and Safety. Available online: https://ntcoss.org.au/ntcoss-submission-to-the-royal-commission-intoaged-care-quality-and-safety/ (accessed on 14 July 2019).

Office of the United Nations High Commissioner for Human Rights. 2009. Thematic Study by the Office of the United Nations High Commissioner for Human Rights on Enhancing Awareness and Understanding of the Convention on the Rights of Persons with Disabilities. Human Rights Council, 10th Session, January 26. A/HRC/10/48. Available online: https://www.un.org/disabilities/documents/reports/ohchr/A.HRC.10.48AEV. pdf (accessed on 13 August 2019).

Perry, Brea, ed. 2015. 50 Years after Deinstitutionalization: Mental Illness in Contemporary Communities. Bingley: Emerald Publishing.

Phillips, Jane, Deborah Parker, and Michael Woods. 2018. We've Had 20 Aged Care Reviews in 20 Years-Will the Royal Commission Be Any Different? The Conversation. September 20. Available online: https://theconversation.com/weve-had-20-aged-care-reviews-in-20-years-will-the-royalcommission-be-any-different-103347 (accessed on 14 July 2019). 
Pyaneandee, Coomara. 2019. International Disability Law: A Practical Approach to the United Nations Convention on the Rights of Persons with Disabilities. Abingdon: Routledge.

Quinn, Gerard, and Michael Stein. 2009. Challenges in Realising the Right to Live in the Community. In Focus on Article 19 of the UN Convention on the Rights of Persons with Disabilities. Edited by Ines Builic and Camilla Parker. London: European Coalition for Community Living, Available online: http://community-living.info/wpcontent/uploads/2014/02/ECCL-Focus-Report-2009-final-WEB.pdf (accessed on 10 October 2018).

Royal Commission into Aged Care Quality and Safety. 2019a. Navigating the Maze: An Overview of Australia's Current Aged Care System: Background Paper 1. Available online: https://agedcare.royalcommission.gov.au/ publications/Documents/background-paper-1.pdf (accessed on 13 July 2019).

Royal Commission into Aged Care Quality and Safety. 2019b. Medium- and Long-Term Pressures on the System: The Changing Demographics and Dynamics of Aged Care: Background Paper 2. Available online: https://agedcare. royalcommission.gov.au/publications/Documents/background-paper-2.pdf (accessed on 13 July 2019).

Royal Commission into Aged Care Quality and Safety. 2019c. Dementia in Australia: Nature, Prevalence and Care: Background Paper 3. Available online: https://agedcare.royalcommission.gov.au/publications/Documents/ background-paper-3.pdf (accessed on 13 July 2019).

Royal Commission into Aged Care Quality and Safety. 2019d. Restrictive Practices in Residential Aged Care in Australia: Background Paper 4. Available online: https://agedcare.royalcommission.gov.au/publications/ Documents/background-paper-4.pdf (accessed on 13 July 2019).

Santegoeds, Jolijin. 2018. Global Ministerial Mental Health Summit. Waarbenjij.nu. October 13. Available online: https://punkertje.waarbenjij.nu/reisverslag/5039902 (accessed on 10 December 2018).

Senate Community Affairs References Committee. 2014. Care and Management of Younger and Older Australians Living with Dementia and Behavioural and Psychiatric Symptoms of Dementia (BPSD). Available online: www.choiceagedcare.com.au/wp-content/uploads/2018/01/Senate-Report-recommendations.pdf (accessed on 13 July 2019).

Senate Community Affairs References Committee. 2015. Violence, Abuse and Neglect Against People with Disability in Institutional and Residential Settings, Including the Gender and Age Related Dimensions, and the Particular Situation of Aboriginal and Torres Strait Islander People with Disability, and Culturally and Linguistically Diverse People with Disability. Available online: www.aph.gov.au/Parliamentary_Business/Committees/Senate/Community_ Affairs/Violence_abuse_neglect/Report (accessed on 13 July 2019).

Senate Community Affairs References Committee. 2016. Indefinite Detention of People with Cognitive and Psychiatric Impairment in Australia. Available online: www.aph.gov.au/Parliamentary_Business/Committees/Senate/ Community_Affairs/IndefiniteDetention45/Report (accessed on 13 July 2019).

Senate Community Affairs References Committee. 2018. Effectiveness of the Aged Care Quality Assessment and Accreditation Framework for Protecting Residents from Abuse and Poor Practices, and Ensuring Proper Clinical and Medical Care Standards are Maintained and Practised: Interim Report. Available online: www.aph.gov.au/Parliamentary_Business/Committees/Senate/Community_Affairs/ AgedCareQuality/Interim_report (accessed on 10 October 2018).

Smith, Anita, and Danny Sullivan. 2012. A New Ball Game: The United Nations Convention on the Rights of Persons with Disabilities and Assumptions in Care for People with Dementia. Journal of Law and Medicine 20: 28-30.

Special Rapporteur on the Rights of Persons with Disabilities. 2019. Report of the Special Rapporteur on the Rights of Persons with Disabilities: Rights of Persons with Disabilities. January 11 A/HRC/40/54. Available online: https://digitallibrary.un.org/record/1663842?ln=en (accessed on 13 August 2019).

Summer Foundation. 2018. 'Young People in Nursing Homes'. Summer Foundation. Available online: https: //www.summerfoundation.org.au/wp-content/uploads/2018/10/YPINH-FACT-SHEET-2.pdf (accessed on 14 July 2019).

Summer Foundation. 2019. Summer Foundation. Available online: https://www.summerfoundation.org.au (accessed on 14 July 2019).

Swaffer, Kate. 2014a. Creating Life with Words: Review of Dementia Awareness Month 2014. kateswaffer.com. October 9. Available online: https://kateswaffer.com/2014/10/09/review-of-dementia-awareness-month-2014/ (accessed on 6 August 2018).

Swaffer, Kate. 2014b. Human Rights in Dementia Care. kateswaffer.com. July 17. Available online: http: //kateswaffer.com/2014/07/17/human-rights-in-dementia-care/ (accessed on 6 August 2018). 
Swaffer, Kate. 2018. Human Rights, Disability and Dementia. Australian Journal of Dementia Care 7. Available online: https://journalofdementiacare.com/human-rights-disability-and-dementia/ (accessed on 10 December 2018).

Swaffer, Kate, and Lee-Fay Low. 2016. Diagnosed with Alzheimer's or Another Dementia: A Practical Guide for What's Next for People with Dementia, their Families and Care Partners. Sydney: New Holland Publishers.

2017. Uluru Statement from the Heart. Available online: https://www.referendumcouncil.org.au/sites/default/files/ 2017-05/Uluru_Statement_From_The_Heart_0.PDF (accessed on 14 July 2019).

UN Commissioner for Human Rights (UNCHR). 2012. The Right of People with Disabilities to Live Independently and Be Included in the Community. Strasbourg: Council of Europe, Available online: rm.coe.int/the-right-ofpeople-with-disabilities-to-live-independently-and-be-inc/16806da8a9 (accessed on 10 December 2018).

UN Committee on the Rights of Persons with Disabilities (UN Disability Committee). 2010. Nyusti and Takács v Hungary, Communication No. 1/2010. Views Adopted by the Committee at Its Ninth Session (15-19 April 2013). CRPD/C/9/D/1/2010. Available online: https://www.ohchr.org/EN/HRBodies/CRPD/Pages/Jurisprudence. aspx (accessed on 13 August 2019).

UN Committee on the Rights of Persons with Disabilities (UN Disability Committee). 2014a. F v Austria, Communication No.21/2014. Views Adopted by the Committee at Its Fourteenth Session (17 August-4 September 2015). CRPD/C/14/D/21/2014. Available online: https://www.ohchr.org/EN/HRBodies/CRPD/ Pages/Jurisprudence.aspx (accessed on 13 August 2019).

UN Committee on the Rights of Persons with Disabilities (UN Disability Committee). 2014b. General Comment No. 1 (2014). Article 12: Equal Recognition before the Law. CRPD/C/GC/1. Available online: https: //tbinternet.ohchr.org/_layouts/15/treatybodyexternal/Download.aspx?symbolno=CRPD/C/GC/1 (accessed on 13 August 2019).

UN Committee on the Rights of Persons with Disabilities (UN Disability Committee). 2014c. General Comment No. 2 (2014). Article 9: Accessibility. CRPD/C/GC/2. Available online: https://tbinternet.ohchr.org/_layouts/15/ treatybodyexternal/Download.aspx?symbolno=CRPD/C/GC/2\&Lang=en (accessed on 13 August 2019).

UN Committee on the Rights of Persons with Disabilities (UN Disability Committee). 2014d. Bacher v Austria, Communication No. 26/2014. Views adopted by the Committee at Its Nineteenth Session (14 February-9 March 2018). CRPD/C/19/D/26/2014. Available online: https:/www.ohchr.org/EN/HRBodies/CRPD/Pages/ Jurisprudence.aspx (accessed on 13 August 2019).

UN Committee on the Rights of Persons with Disabilities (UN Disability Committee). 2015. Guidelines on article 14 of the Convention on the Rights of Persons with Disabilities: The Right to Liberty and Security of Persons with Disabilities. Available online: www.ohchr.org/EN/HRBodies/CRPD/Pages/GC.aspx (accessed on 21 March 2019).

UN Committee on the Rights of Persons with Disabilities (UN Disability Committee). 2017. General Comment No. 5 (2017) on Living Independently and Being Included in the Community. CRPD/C/GC/5. Available online: https://tbinternet.ohchr.org/_layouts/15/treatybodyexternal/Download.aspx?symbolno=CRPD/C/ GC/5\&Lang=en (accessed on 13 August 2019).

UN Committee on the Rights of Persons with Disabilities (UN Disability Committee). 2018. General Comment No. 6 (2018) on Equality and Non-Discrimination. CRPD/C/GC/6. Available online: https://tbinternet.ohchr. org/_layouts/15/treatybodyexternal/Download.aspx?symbolno=CRPD/C/GC/6\&Lang=en (accessed on 13 August 2019).

World Health Organisation. 2015. Call for Action by the Participants in the First WHO Ministerial Conference on Global Action against Dementia (Geneva, 16-17 March 2015). Available online: www.who.int/mental_health/ neurology/dementia/call_for_action/en/ (accessed on 10 December 2018).

World Health Organisation. 2017a. Creating Mental Health and Related Services Free from Coercion, Violence and Abuse. WHO/MSD/MHP/17.6. Available online: www.who.int/mental_health/policy/quality_rights/guidance_ training_tools/en/ (accessed on 10 December 2018).

World Health Organisation. 2017b. Improving Mental Health and Related Service Environments and Promoting Community Inclusion. WHO/MSD/MHP/17.3. Available online: www.who.int/mental_health/policy/quality_ rights/guidance_training_tools/en/ (accessed on 10 December 2018).

World Health Organisation. 2017c. Strategies to End the Use of Seclusion, Restraint and Other Coercive Practices. WHO/MSD/MHP/17.9. Available online: www.who.int/mental_health/policy/quality_rights/guidance_ training_tools/en/ (accessed on 10 December 2018).

World Health Organisation. 2018. Dementia: Key Facts. December 12. Available online: www.who.int/news-room/ fact-sheets/detail/dementia (accessed on 27 July 2018). 
Williams, John. 2011. Care Home Design and Human Rights. Elder Law Journal 1: 395-402.

Wood, Patrick. 2019. 'Terrified' Ageing Child Abuse Survivors Begin Transition into Aged Care'. ABC News Breakfast. April 5. Available online: https:/www.abc.net.au/news/2019-04-05/aged-care-sector-prepares-forforgotten-australians-after-abuse/10969144 (accessed on 14 July 2019).

Woolford, Marta, and Joseph Ibrahim. 2017. There's No Need to Lock Older People into Nursing Homes 'For Their Own Safety'. The Conversation. March 17. Available online: https://theconversation.com/theres-no-need-tolock-older-people-into-nursing-homes-for-their-own-safety-73954/ (accessed on 10 December 2018).

Woolford, Marta H., Carolina Weller, and Joseph E. Ibrahim. 2017. Unexplained Absences and Risk of Death and Injury among Nursing Home Residents: A Systematic Review. Journal of the American Medical Directors Association 18: 1-15. [CrossRef] [PubMed]

(C) 2019 by the authors. Licensee MDPI, Basel, Switzerland. This article is an open access article distributed under the terms and conditions of the Creative Commons Attribution (CC BY) license (http://creativecommons.org/licenses/by/4.0/). 